\title{
To Be Enduring: The National Union Catalog Of Manuscript Collections
}

$I^{\mathrm{T}}$ T IS WITH PROFOUND DISQUIETUDE, abundant rue, and a shattering sense of shame that I approach my subject. These distressing symptoms are, moreover, only aggravated and further intensified by feelings of pity for your pretty patience and submissive endurance. There is no lack of material, to be sure, but the recital of entries in a bibliography, however exhaustive and detailed it may be, is per se inimical to faultless prose and, at least for me, impossible of dazzling oratorical effect. Worse, it is in itself neither diverting nor inflammatory; it cannot arouse but it can disturb repose.

An alternative would be, of course, to select and present "elegant extracts" from the literature, but inevitably you would have heard them all before or read them all before. It is a penalty of the profession of our choice that our lives are spent following one another from meeting to meeting and listening to one another with polite and collective indifference. In consequence, except where brazen flattery is intended, the anthologist's indolent style should be, from humane considerations, daintily avoided, even in pronouncements on the state of the art.

Mr. Mearns is Chief, Manuscript Division, and Assistant Librarian for the American Collections, Library of Congress. This paper was presented at the Rare Books Conference sponsored by the ACRL Rare Books Section at the University of Virginia, Charlottesville, June 18, 1959.
But you have now perceived the alarming fact that my poor muse cannot compete in extolling the virtues and expounding the values of the National Union Catalog of Manuscript Collections. It has had its persuasively eloquent advocates: Herbert Kellar in the Annual Reports of the American Historical Association; Francis Berkeley in the Proceedings of the American Philosophical Society; Robert Land in The American Archivist. It has had also its rhapsodists, its lyricists, its librettists, its frenzied partisans. It has had its architects and planners; its extravaganzas and its grandiosities. It has had its skeptics and its cynics; its sages and its seers. It has had dedicated servants. It has had Jobs to breathe on the heart. It has had scores of grandfathers and foster fathers. It is the child of a ghost: the ghost of Henry Ford.

It seems likely that a national union catalog of manuscript collections has always been predictable, for it derives, at least in part, from the American genius for dispersal. More than a century ago de Tocqueville wrote his familiar criticism: "The public administration is, so so speak, oral and traditionary. But little is committed to writing, and that little is wafted away forever, like the leaves of the Sibyl, by the smallest breeze." As long ago as 1843, Archibald Alison, in his best-selling History of Europe, paraphrased this dictum, insisting "that so wholly are they [i.e. the Americans $_{\text {] }}$ regardless of historical records or monuments that half a century hence the national annals even of these times could only be written from the 
archives of other states." This drew a protest from the reviewer for London's Athenaeum, who declared: “Assuming that there had been indifference on the part of the government, the Historical Commemorations alone, a custom peculiar to America, must, from their nature, tend to collect and preserve such a mass of historical information, as no other country has ever possessed, or can ever hope to possess. Every town, indeed, has its history and its historical records; and the labour of selection will be the great difficulty in the way of the future historian."

No, we are not now, and have never been, a one-basket people, and in recent years this scattering tendency has been adopted, promoted, and even sanctified by the chief magistrates of the land. It is not to be wondered that the anguished victims of this heresy should pray loudly for the repentance of their tormentors and meanwhile seek a salve which would assuage their wretchedness. Ray Allen Billington diagnosed the ailment in these words: "The quantity of manuscript materials is so large, and the holdings so widely dispersed in archival establishments, universities, research and public libraries, historical societies, and private collections, that the complete examination of all sources for any single problem, no matter how minute, would exhaust the energy and financial resources of the most diligent scholar." Dr. Billington's prescription: a union catalog.

It is usual to date the origin of the union catalog of manuscripts movement in 1939, when the American Historical Association established a special committee on manuscripts. The committee reported in 1946, and revised its report in 1947, recommending the establishment of such an apparatus in the Library of Congress or other appropriate repository and calling for a budget of a quarter of a million dollars to be expended over a three-year period. In 1948 the special committee was dissolved; its functions, including the function of fund-raising, passing to a joint committee of the Society of American Archivists and the Association for State and Local History. The joint committee was instructed to "plan a program designed to accomplish ultimately three things: (1) prepare a union inventory in this country; (2) make known in same way the yearly current accessions of public repositories; (3) establish ways and means whereby repositories can cooperate rather than compete for American historical material." With respect to the realization of its first and second objectives the joint committee can look back to the accomplishments of a decade with complete and purring satisfaction. The third presumably lingers stubbornly on the agenda.

Actually the idea of a union catalog of manuscripts was no startling novelty. As long ago as 1894, the prophetic Mr. A. Howard Clark of the Smithsonian Institution had told a gathering of scholars: "The time may be at hand for this association to prepare a complete, classified, and fully indexed analytical bibliography of all works in manuscript or print, in English or in foreign tongues, concerning the history of America."

There was tangible evidence of the feasibility of such an undertaking. In the closing years of the seventeenth century, a catalog of manuscripts in the public and private collections in the United Kingdom, including librorum manuscriptorum viri sapientissimi Samuelis Pepysii had been compiled and published at the Sheldonian Theater, Oxford, in two stout folios, in 1697. This had been prepared under the direction of a gifted divine, Edward Bernard, for eighteen years Savilian Professor of Astronomy at the University. Because of his distinguished mastery of catalogistics, I insert in the record a passage taken from David Charles Douglas' English Scholars: 
This extraordinary man ... was born in 1638, and he was to play an important part in the development of scientific studies at Oxford. But his interests were encyclopedic, and he turned easily from mathematics to ancient oriental literature, even going so far as to prepare an edition of Josephus and to seek a chair in this subject at the University of Leyden. Bernard's reputation as a scholar extended far beyond the boundaries of Oxford, or even of England, and, the friend of Mabillon, it was said of him by a continental critic that "few in his time equalled him in learning and none in modesty." It was fortunate for historical scholarship that such a man as this began in 1692 to prepare a comprehensive catalogue of the Bodleian MSS, and it was still more fortunate that before he had been many years at his task he found in ${ }_{[}$Humphrey ${ }_{1}$ Wanley the young scholar who in all England was the best qualified to assist him.

"I conceive it as part of a LibraryKeeper's duty," wrote Wanley about this time, "to know what books are extant in other Libraries besides his own," and here he indicated what was to be the primary virtue of the critical catalogue in whose construction he was assisting. The compilers of Barnard's Catalogue as it is commonly known ${ }_{j}$ did not confine their attention to MSS in the Bodleian Library itself but placed contemporary scholarship under a far greater debt by considering also MSS existing elsewhere in England. Such a labour necessitated wide collaboration, and as the preface to the book showed, many notable scholars took a share in the final production. . . . It was a distinction ... to be intimately connected with a work of co-operative scholarship as important as Bernard's Catalogue, for the volume was one of the major achievements of the Oxford school of Saxonists, and it gave a great impetus to medieval studies. One of the chief difficulties of all previous investigators into the early medieval history of England had been that any proper comparative study of their chief sources was impossible for them, owing to their ignorance of what MSS existed, and where they were to be found.
Whether or not on Sunday evening, April 10, 1949, the members of the Joint Committee on Historical Manuscripts, assembled at the Princeton Inn, burned an offering in honor of the Rev. Dr. Bernard, or, as would have been more appropriate, contented themselves by proposing a series of toasts to the memory of that perspicacious prototype, is not clear from the fragmentary sources which survive. It is, however, reasonable to conclude, from certain recently recovered artifacts, and from occasionally inaudible wire-tappings, that their concern for a union catalog had taken a grimly realistic, or," as they elected to put it, a "grass-roots," turn. It is also ascertainable that the Library of Congress had moved in from the dry periphery and become drenchingly involved in the deliberations. The observer from that sympathetic repository, in a yellowing travel report to his master, wrote with the pride that only self-conscious practicality cannot disguise: "I made it very clear that a condition precedent to any such enterprise was the assurance of complete and continuous cooperation from the institutions and individuals which and who would be expected to participate." He added, a little irrelevantly, "The meeting broke up about midnight."

And thus the union catalog was wilfully shorn of all prospective frills, trappings, and glittering allurements. Two years later the then Librarian of Congress expressed a willingness to provide the infant, when born, with a home. There remained, however, one ponderous preliminary to seeking dispensation from a foundation: a uniform and standard practice for describing manuscripts. This practice must be acceptable to most curators and generally useful to scholars. In 1952, Luther Evans, still in a bibliothecal incarnation, announced in his annual report: "Rules for the cataloging of all manuscript materials in the Library of Congress are ... in prepara- 
tion. Advice has been sought from a number of experts on manuscript collections, including members of the Joint Committee on Historical Manuscripts $\ldots$ and a representative of the National Historical Publications Commission. The completion of these rules will make it possible for the Library to proceed with the development of another important cooperative bibliographic project: the National Register of Manuscript Collections."

To draft the rules, Dr. Evans had designated a working party drawn from appropriate divisions in the processing and reference departments. I will not repeat the history of that consecrated group of Clio's handmaidens and handymen. To do so would be to violate the literary property rights, as yet not dedicated to the public, of my erstwhile and esteemed colleague, Robert Land, who feelingly communicated its earlier chapters to the Mississippi Valley Historical Society in the spring of 1954. I may, however, without risk of infringement, be permitted to say that the proceedings were conducted with exemplary decorum and constant assurances of mutual consideration and respect, that visiting counselors from the outer-world consistently offered benedictions and made signals of approval, and that decisions or such perplexities as "choice of entry," "form of entry," and "form, if not original," can be, for the initiate, somewhat enervating. If anyone object that it took longer to draft rules for cataloging manuscript collections than it did for the gentlemen in Philadelphia to draw up the Constitution of the United States, let the complainant be reminded that the delegates to the Federal convention were a bunch of amateurs. Agreement for them was easy.

In a more serious sense, however, it should be pointed out that no catalog can be, for everyone who may consult it, a precision instrument, neither can reference to the entries in it be substi- tuted for an examination of the works which they describe. A good catalog, a sound catalog, a responsive catalog must, however, present a degree of exactitude which will permit an investigator to eliminate from consideration those materials which, obviously, are unrelated to his enquiry. It should, moreover, be borne in mind that large bodies of personal papers and public records are complicated by the miscellaneity of their contents, their origins, the extent of their completeness or incompleteness, and the varying conditions to which their availability may be, in whole or in part, subjected. The elements which in combination constitute their distinguishing characteristics must be identifiable and identified. The codifiers had, in other words, to devise rules which might be consistently applied to inconsistent, dissimilar and ruggedly, obstinately individualistic and inert collections. Again, the rules had to be so designed as to commend their adoption by those repositories upon whose active, steady participation the utility of a national catalog would depend.

A draft was published in the spring of 1953, and widely distributed for comment. The rules received general approbation and the section of the final draft dealing with collections was ratified by ALA in 1954.

Therefore, careful studies were conducted at the Library of Congress of the editorial costs that would be required to bring the catalog into being, based upon replies to a questionnaire which had determined the volume of work which might be anticipated over a fiveyear period.

At a meeting called by the Librarian of Congress, L. Quincy Mumford, on March 7, 1957, attended by members of his staff and by Francis L. Berkeley, Jr., curator of manuscripts at the University of Virginia, Lester J. Cappon, president of the Society of American Archivists and director of the Institute 
of Early American History and Culture, and Boyd C. Shafer, executive secretary of the American Historical Association, it was determined that the Library of Congress should take the initiative by applying to the foundation for a grant sufficient to meet the obstetric charges.

The proposal received wide, cordial, and sometimes expository scholarly support. Thus, for example, the director of a library of early Americana at a midwestern university, wrote: "Manuscripts have a way of defying logic as to their ultimate resting place. Often they move thousands of miles from their place of origin. Despite efforts of many repositories to publicize their holdings, the information does not always reach the persons who have most need of it. By collecting and concentrating this information in one file, tremendous service will be rendered all research workers."

A professor at Harvard could, he declared, "imagine nothing of greater importance to the world of American scholarship than the proposed National Union Catalog of Manuscripts." A state archivist could not, he said, "think of a more worthwhile expenditure of funds." A historian in a southern university remarked: "One of the great and serious obstacles to scholarly work-and it is becoming more formidable all the time -is the great cost of itinerant research. Many people cannot raise the large amounts of money necessary for itinerant research on a considerable scale. So they either forego the books they'd like to write; or they write superficial volumes." A past president of the American Historical Association termed it "a most important venture and one that badly needs to be done." The editor-in-chief of the papers of a distinguished New England family let it be known that he had grown "impatient with counsels of perfection that still seem to obstruct the way to the grand objective."

Such encomia were comparable to endorsements of a beauty cream by the
Duchess of Windsor or Dame Marilyn Monroe and performed a comparable service in selling the product. Last December, as the American Historical Association was taking over Washington's own Mayflower it was announced, with a caution not to tell before the twentyeighth, that the Library of Congress would establish an inventory of important manuscript collections throughout the nation with a grant of $\$ 200,000$ just received from the Council on Library Resources, Inc. The press-release, with unaccustomed excitement, explained: "The dream of historians for three-quarters of a century, it is expected to be of invaluable aid to scholars seeking the 'primary' source materials they need for research-in history, literature, economics, science, etc." As to the immediate objective it was said to be the preparation of uniform descriptions of some 24,000 collections known to exist in about seventy-five cooperating libraries and archives as well as of 3,000 collections in the Library of Congress. The announcement stated that the program would be assisted by an advisory committee representing the interested scholarly councils, associations, and academies. It continued: "The Library of Congress will now request data on standard forms or data sheets from institutions holding manuscript collections. On the basis of these reports, the Library will prepare catalog entries and publish catalog cards for them. Each entry will contain the description and location of a collection and will list the persons, organizations, places, and subjects primarily represented in it."

That was, as I say, six months ago. Meanwhile the infant has been duly nursed, swaddled, and cherished. It has made satisfactory gains in weight. The atmosphere has been sprayed with insecticide and a few persistent bugs have been hopefully removed. Definitions have been formulated and letters of explanation and instruction have been 
prepared. The reporting forms have been carefully and tenderly vised, revised, and rerevised. They are understood to be wearing the perfection of the untried. The Advisory Committee has been convened and has made helpful suggestions. A manuscript section has been established in the processing department's descriptive cataloging division and its staff (complete with typist) has been recruited. Heading it is Lester K. Born, a gentleman of wide experience and many accomplishments, especially in the archival sciences. It is rumored that Dr. Born will soon make the grand tour of contributing repositories. The first cards have issued from the press.

And so, without unseemly haste, the National Union Catalog has attained reality and status. But its future is sternly and strictly in your hands-I should say it is in our hands for (as an inhabitant of the reference department) my relation to the catalog is identical to the relation of any other manuscript custodian. Will it become, in the course of its first quinquennium, a great scholarly apparatus serving the entire nation? Will it fulfill the expectations and aspirations of its earlier and ardent proponents? Will it work economies by removing futility from itinerant research? Will it assure better, more definitive coverage of the sources? Will it gather such momentum that its continuation, after the expiration of the grant, will be safe and certain?

I do not know. But this I do know: it will be as good or bad, effective or ineffective, sound or unsound, comprehensive or perilously incomplete as we determine it shall be. It is up to us to give it dimension and character. The responsibility is not to be evaded. The work that it will impose will be hard work. It will be taken from our hides. It is unlikely that there will be appropriations, subventions, gifts, at least for the present, to allow the engagement of ad- ditional personnel to prepare those reporting forms on which the catalog will be builded.

Fortunately, however, this very situation has been foreseeable and foreseen. It is now five years since the learned Berkeley, in a clear and steady voice, uttered simple if poignant truth to a Philadelphia audience, when he said: "To be enduring, and even to approach completeness, it must be the product, not of a temporary and prodigious effort, but rather a creation of day-to-day routine by the normal staffs of manuscript repositories."

And so it must, for the union catalog is, and will always remain, a ward of the realm. The creature of cooperation, it must thrive or languish to the extent of selfless interest and tenacious fostering. I exhort you, therefore, to give it your constant, tangible, and ungrudging support. And give it cheerfully and generously and with all the signs of grace. Reluctance to participate is, of course, unthinkable; but if any, for whatever reason, venture to demur or to protest inabilities, let him be reminded that he will be subjected to strong compulsions to join in the exercise and that they will come, not from his professional associates, but from those far more puissant constituents for whose service he exists.

But this is putting the case in negative terms. Positively, the union catalog bestows promises enough, conveniences enough, advantages enough to command our collective allegiance and strenuous striving.

Some years ago an Oriental tentmaker dashed off some lines which were later rendered by a gifted interpreter as:

Alas, that Spring should vanish with the Rose!

That Youth's sweet-scented Manuscript should close!

Perhaps a union catalog's the way Again to open it, perfume and all, who knows? 